\title{
ANALISIS TRANSIEN UNTUK MEMPREDIKSI KEDALAMAN PENGERASAN PERMUKAAN PADA BAGIAN KRITIS CRANKSHAFT
}

\section{TRANSIENT ANALYSIS TO PREDICT DEEP HARDENING AT CRITICAL SEGMENT OF CRANKSHAFT}

\author{
Harry Purnama, Dyah Kusuma Dewi, Muizudin Azka \\ Pusat Teknologi Industri Manufaktur, TIRBR - BPPT, Gd. Teknologi 2 Puspiptek, Serpong. \\ e-mail : hrrypn@yahoo.com, kusumaning.dyah@gmail.com, mz.azka@yahoo.com
}

\begin{abstract}
Abstrak
Dalam penelitian ini simulasi dinamis transien diterapkan pada crankshaft dengan silinder ganda empat stroke. Analisis elemen hingga dilakukan dengan menggunakan software bantu ANSYS untuk memperoleh tegangan von-misses di lokasi kritis, sedangkan permodelan 3D menggunakan software 3D modeling CATIA. Beban dan kondisi batas yang diterapkan sesuai dengan kondisi engine mounting di ANSYS. Simulasi transien di mana pembebanan didasarkan pada waktu diharapkan dapat memperoleh kedalaman dari konsentrasi tegangan. Hal ini dapat membantu untuk proses $\mathrm{m}$ dari crankshaft, pengerasan permukaan.
\end{abstract}

Kata kunci : Analisa Transient, Time Step, ANSYS, Crankshaft, Pengerasan Permukaan.

\begin{abstract}
In this study a transient dynamic simulation was conducted on a crankshaft for double cylinder four stroke engine. Finite element analysis was performed to obtain of von-misses stress at critical locations using ANSYS, while the model creation can be created by well known 3D modeling software CATIA. The load and boundary conditions were applied according to the engine mounting conditions in ANSYS. The simulation with the proper time step be expected depth of stress concentration. It can help to the next process of crankshaft, surface hardening.
\end{abstract}

Keywords : Transient Analysis, Time Step, ANSYS, CrankShaft, Surface hardening

Diterima (received) : 12 Juli 2016, Direvisi (reviewed) : 18 Juli 2016, Disetujui (accepted) : 28 Juli 2015

\section{PENDAHULUAN}

Crankshaft merupakan komponen dalam mesin dengan geometri yang kompleks, di mana bagian utama crankshaft terdiri dari poros yang berputar pada bantalan utama, crankpin dan counterwight. Crankshaft berfungsi mengubah gerak resipro dari piston menjadi gerak rotasi dalam mekanisme pembakaran internal. Gaya piston dan gaya inersia piston yang dihasilkan dari proses pembakaran internal mengakibatkan pembebanan fluktuatif berupa beban torsional dan beban tekuk ${ }^{(1)}$. Oleh karenanya crankshaft harus cukup kuat untuk menahan gaya-gaya yang bekerja selama mesin beroperasi.

Sudah sejak lama metode desain crankshaft dikembangkan melalui perhitungan manual dengan rumus teroritis sampai pada penggunaan software bantu CAD serta CAE (2). Dari hal tersebut, tantangan enjinir pada saat ini lebih besar untuk dapat mengembangkan desain yang terjamin kelayakannya.

Desain geometri merupakan faktor utama dari kemampuan crankshaft, akan tetapi pemilihan dan perlakuan permukaan material baja juga menentukan ketahanan komponen. Perlakuan permukaan pada crankshaft 
secara umum berupa pengerasan permukaan yang mana digunakan untuk meningkatkan ketahanan dari material baja tanpa mempengaruhi sifat makanikal bagian dalam baja. Perpaduan parameterparameter yang tepat membuat crankshaft mampu bertahan pada torsi tinggi, tahan terhadap fatique serta memiliki keseimbangan karakteristik yang baik ${ }^{(5)}$.

\section{Studi Literatur}

Montazersadgh and Ali Fatemi. ${ }^{(3)}$ telah mempelajari simulasi dinamik dari crankshaft dengan material baja tempa, analisa FEA digunakan untuk menentukan besarnya variasi tegangan di lokasi kritis. Hasil proses optimisasi didapat berupa pengurangan berat crankshaft dan meningkatnya kekuatan fatique.

R. J. Deshbhratar, and Y.R Suple. ${ }^{(6)}$ telah menganalisa crankshaft dengan 4 silinder dan memodelkan dengan software Pro/E kemudian diimport ke ANSYS. Analisa menunjukan deformasi maksimum berada pada jurnal crankshaft, sedangkan untuk tegangan maksimum berada pada fillet antara jurnal crankshaft dan pin-crank. Hingga pada kesimpulan bahwa pada titik tersebut sangat rawan terhadap retak dan mengakibatkan umur material berkurang.

K. D. Alex et al. (4) telah memodelkan crankshaft dengan CATIA kemudian disimulasikan dengan ANSYS untuk mendapatkan tegangan ekuivalent dan tegangan geser. Nilai karbon dari material baja yang digunakan sebesar $0.3 \% \sim 0.5 \%$, penggunaan material baja karbon sedang dengan perlakuan permukaan dan menambahkan radius pada fillet dapat mengurangi konsentrasi tegangan.

Singh, Anku Kumar. ${ }^{(5)}$ telah melakukan identifikasi terhadap perlakuan permukaan pada crankshaft dengan induction hardening untuk meningkatkan kekerasan permukaan. Pemilihan induction hardening karena geometri crankshaft yang kompleks, dengan induction hardening dirasa lebih memudahkan proses perlakuan permukaannya.

Mayer H. M et al. ${ }^{(8)}$ telah mengaplikasikan deep rolling dan induction hardening untuk meningkatkan kekerasan dan ketahanan pada permukaan crankshaft. Hasil dari analisa tegangan sisa pada beberapa bagian crankshaft menunjukan bahwa dengan meningkatkan gaya rolling saat proses manufaktur serta melakukan proses induction hardening dapat mengingkatkan nilai tegangan tekan sehingga dapat juga meningkatkan masa pemakaian dari suatu crankshaft.

Makalah ini menyajikan metode analisa untuk menentukan kedalaman pengerasan permukaan dari crankshaft ditinjau dari konsentrasi tegangan ekuivalen yang akan terjadi menggunakan software bantu ANSYS. Studi ini juga menyertakan desain, ukuran mesh dan konvergensi untuk kebutuhan analisis. Disamping itu identifikasi kondisi batas dilakukan menyesuaikan dengan pembebanan dari desain.

\section{Metodologi}

Sifat spasial yang kompleks dari crankshaft membuat pendekatan elemen hingga menjadi relatif sulit. Permodelan crankshaft dilakukan menggunakan software CATIA dan simulasi analisis menggunakan ANSYS. Hasil analisis akan diambil dari berbagai modus tegangan crankshaft dengan mempertimbangkan beban tertentu dan kondisi batas analisis transient.

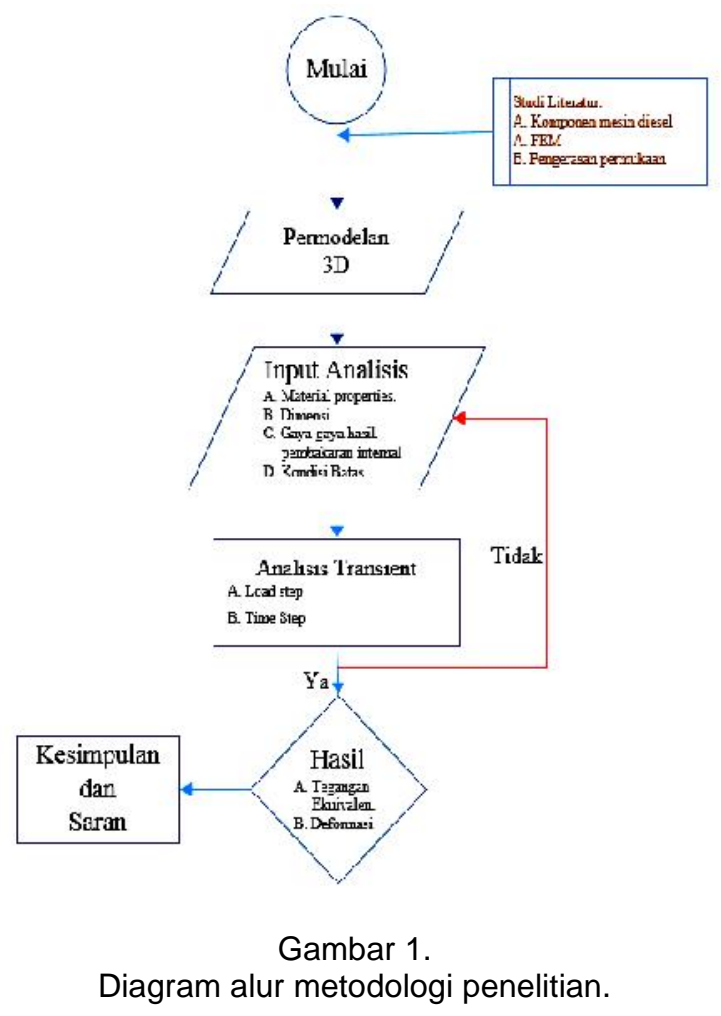

\section{Parameter mesin diesel dan gaya pada crankshaft}

Makalah ini menggunakan crankshaft dari mesin diesel yang mempunyai dua silinder dengan berkapasitas 909cc sebagai insial desain. Parameter teknis dari mesin pada tabel 1 digunakan untuk mendapatkan input berupa gaya crankshaft sebagai berikut: 
Analisis Transien untuk Memprediksi Kedalaman Pengerasan Permukaan pada Bagian Kritis Crankshaft (Harry Purnama, Dyah Kusuma Dewi, Muizudin Azka)

Tabel 1.

Parameter teknis

\begin{tabular}{clc}
\hline No & \multicolumn{1}{c}{ Parameter Teknis Mesin Disel } & Nilai \\
\hline 1 & Masa Piston $\left(m_{\text {pisotn }}\right)$ & $0.553 \mathrm{Kg}$ \\
2 & Diameter Piston $(\mathrm{D})$ & $0.083 \mathrm{~m}$ \\
3 & Massa Connecting Rod $\left(\mathrm{m}_{\text {Con-Rod }}\right)$ & $0.909 \mathrm{Kg}$ \\
4 & Panjang Connecting Rod $(I)$ & $0.1405 \mathrm{~m}$ \\
5 & Stroke & $0.084 \mathrm{~m}$ \\
6 & Perpindahan sudut crank dari TDC $(\theta)$ & $0,360,270 \mathrm{rad}$ \\
7 & Kecepatan angular $(\omega)$ & $3600 \mathrm{rpm}$ \\
8 & Crank Throw $(r)$ & $0.042 \mathrm{~m}$ \\
\hline
\end{tabular}

Dari parameter di atas dapat digunakan sebagai input dalam persamaan di bawah ini:

$$
m_{\text {recipro }}=m_{\text {piston }}+\left(0.33 \times m_{\text {con-rod }}\right) \ldots
$$

Massa bagian recipro dapat digunakan dalam persamaan untuk mendapatkan momen inersia crankshaft:

$$
i=m_{\text {recizr } 0} x r^{2} \text {. }
$$

Penentuan besar gaya inersia piston berdasarkan kecepatan dan percepatan gerak translasi piston dan connecting rod, persamaanya adalah sebagai berikut:

$$
\begin{aligned}
& v=\omega x r\left(\sin \theta+\left(\frac{r}{2 l}\right) \sin 2 \theta\right] \ldots \ldots \ldots \ldots \ldots \\
& a=\left(\omega^{2}\right) x r\left(\cos \theta+\left(\frac{r}{l}\right) \cos 2 \theta\right) \ldots \ldots \ldots \ldots \\
& F_{\text {ip }}=m x\left\{\left(\omega^{2}\right) x r\left(\cos \theta+\left(\frac{r}{l}\right) \cos 2 \theta\right)\right) \ldots .
\end{aligned}
$$

$v$ menunjukan kecepatan piston pada sudut tertentu sehingga fungsi $v$ dapat dijadikan $a$, percepatan akan menjadi variable dalam gaya inersia piston dengan mengalikan massa bagian recipro seperti pada persamaan (1). Sedangkan gaya pembakaran atau disebut gaya pison persamaannya adalah sebagai berikut:

$$
F_{p}=\left(P_{\text {total }}\right) \frac{\pi D^{2}}{4} .
$$

$P_{\text {total }}$ adalah tekanan ruang bakar yang terjadi pada saat pembakaran internal, terdiri dari tekanan silinder dikurangi oleh tekanan crankcase.

\section{Pemilihan material dan perlakuan permukaan}

Pemilihan material untuk komponen dengan geometri yang komplek seperti crankshaft, tidak hanya menentukan komposisi baja, tetapi juga tingkat sifat mekanik yang sesuai dengan spesifikasi.

Material baja VCN 150 identik dengan AISI 4340 yang secara umum digunakan untuk pembuatan crankshaft. VCN 150 mempunyai spesifikasi teknis seperti dalam tabel 2.

Material baja VCN-150 mempunyai nilai brinell hardness sebesar $280 \sim 300 \mathrm{HB}$, nilai tersebut ekuivalen dengan nilai rockwell hardness sebesar $29.2 \sim 32.2 \mathrm{Hrc}$. Setelah mendapatkan perlakuan panas nilai brinell

\begin{tabular}{|c|c|c|c|c|c|c|c|c|c|c|c|c|c|c|c|}
\hline \multirow[b]{2}{*}{ Grade } & \multirow[b]{2}{*}{ C } & \multirow[b]{2}{*}{ Si } & \multirow[b]{2}{*}{$\mathrm{Mn}$} & \multirow[b]{2}{*}{$\mathbf{P}$} & \multirow[b]{2}{*}{ s } & \multirow[b]{2}{*}{$\mathrm{Cr}$} & \multirow[b]{2}{*}{ Mo } & \multirow[b]{2}{*}{$\mathrm{Ni}$} & \multirow[b]{2}{*}{ HB } & \multirow{2}{*}{$\begin{array}{c}\text { Tensile } \\
\text { Strength } \\
\text { (KgF/mm2) }\end{array}$} & \multicolumn{4}{|c|}{ Heat Treatment $\left({ }^{\circ} \mathrm{C}\right)$} & \multirow{2}{*}{$\begin{array}{l}\text { Hardness } \\
\text { (Hrc) }\end{array}$} \\
\hline & & & & & & & & & & & Normalizing & Anealing & Quenching & Tempering & \\
\hline & & & & & & & & & 280 & 95 & 820870 & $\begin{array}{c}820 \\
870\end{array}$ & 810860 & & \\
\hline \multirow[t]{2}{*}{$\begin{array}{l}\text { VCN } \\
150\end{array}$} & $\begin{array}{c}0.36 \\
0.43\end{array}$ & $\begin{array}{c}0.15 \\
0.35\end{array}$ & $\begin{array}{c}0.60 \\
0.90\end{array}$ & $\begin{array}{l}\text { Max } \\
0.03\end{array}$ & $\begin{array}{l}\text { Max } \\
0.03\end{array}$ & $\begin{array}{c}0.60 \\
1.00\end{array}$ & $\begin{array}{c}0.15 \\
0.30\end{array}$ & $\begin{array}{l}1.60 \\
2.00\end{array}$ & & & $\begin{array}{c}\text { Air } \\
\text { Cooling }\end{array}$ & $\begin{array}{l}\text { Slow } \\
\text { Cooling }\end{array}$ & $\begin{array}{c}\text { Oil } \\
\text { Cooling }\end{array}$ & $\begin{array}{c}180 \\
200\end{array}$ & $45 \quad 55$ \\
\hline & & & & & & & & & 300 & 102 & & & & & \\
\hline
\end{tabular}
hardnes maupun rockwell hardness dapat mengalami peningkatan, untuk lebih detailnya akan diuraikan dalam tabel 3 .

Tabel 2.

Spesifikasi mekanikal 
Tabel 3.

Nilai kekerasan material baja VCN 150

\begin{tabular}{lccc}
\hline $\begin{array}{c}\text { Perlakuan } \\
\text { permukaan }\end{array}$ & HB & Hrc & $\begin{array}{c}\text { Tensile } \\
\text { Strength } \\
\left(\mathrm{KgF} / \mathbf{m m}^{2}\right. \\
\text { ) }\end{array}$ \\
\hline Sebelum & $280 \sim 300$ & $\begin{array}{c}29.2 \\
\sim \\
32.2\end{array}$ & $95 \sim 102$ \\
& & 32.5 & \\
Setelah & $428 \sim 570$ & $45 \sim$ & $145.5 \sim$ \\
& & 55 & 199.5 \\
\hline
\end{tabular}

Sumber: ficjp.com \& iron-

foundry.com/castings-hardness.html

Dengan nilai kekerasan dari baja VCN 150 di atas, dimungkinkan masih perlu untuk ditingkatkan sehingga didapatkan nilai kekuatan tensil dan kekuatan luruh yang lebih baik dari material baja VCN 150. Penggunaan metode perlakuan permukaan yang dapat memenuhi spesifikasi kekerasan dan kekuatan material baja adalah dengan proses pengerasan (hardening) dan pemanasan (tempering). Proses hardening memiliki beberapa fungsi antara lain menaikan ketahanan aus suatu material baja, menaikan kekerasan permukaan hingga sedalam $0.5 \mathrm{~mm}$, menambahkan ketahanan permukaan terhadap beban mekanis dan memperbaiki ketahanan fatique.

Proses hardening pada permukaan dilakukan dengan beberapa metode antara lain induction hardening, flame hardening, case hardening dan nitride hardening (gas hardening). Setiap metode memiliki kelebihan dan kekurangan, bergantung pada penggunaan dan fungsinya, akan tetapi menggunakan metode satu dan yang lainnya hasil yang diinginkan adalah nilai kedalaman pengerasan. Kedalaman ini ditentukan dari kebutuhan desain komponen yang dilakukan.

Hardening pada permukaan banyak diaplikasikan pada komponen yang mempunyai bidang geometri yang komplek salah satunya crankshaft ${ }^{(10)}$.

\section{Permodelan 3D}

Permodelan 3D crankshaft dari insial desain dilakukan dengan menggunakan CATIA, geometri dari crankshaft ditentukan berdasar kebutuhan suatu mesin diesel seperti yang tersebut di atas. Pada gambar 1. menunjukkan model digital dari crankshaft yang digunakan dalam penelitian ini sedangkan gambar 2. Menunjukan asembli dari geometri crankshaft, connecting rod dan piston sebelum dilakukan proses simulasi.

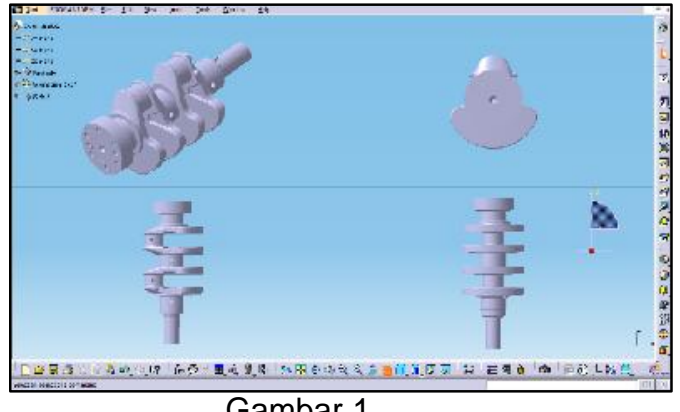

Gambar 1.

Permodelan 3D crankshaft

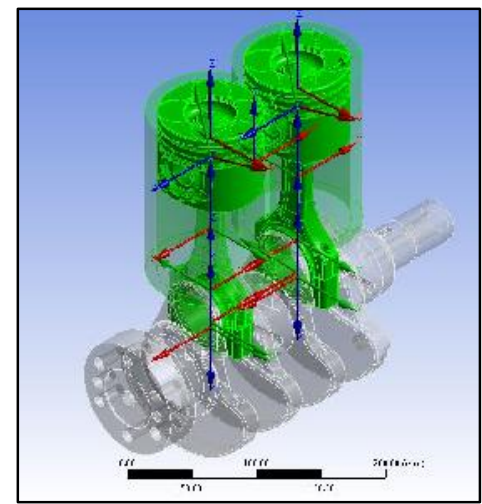

Gambar 2.

Permodelan 3D geometri piston, connecting rod dan crankshaft

\section{Analisis Transient dan Hasil}

\section{Analisis Transient}

Analisis pembebanan dinamis pada crankshaft lebih realistis dibandingkan analisis statis, di mana analisis statis memberikan hasil yang mungkin tidak mencerminkan kondisi operasi ${ }^{(7)}$. Analisis transient merupakan salah satu analisis dinamis yang digunakan untuk menentukan respon dinamik dari struktur pada setiap beban tergantung waktu. Analisis transient menggunakan skala waktu dari pembebanan sehingga inersia atau efek redaman dianggap penting. Oleh karena itu itu pada proses analisis crankshaft ini dilakukan dengan mendekati kondisi sesungguhnya.

Analisis crankshaft dilakukan dengan menggunakan kecepatan operasi sebesar $3600 \mathrm{rpm}$. Analisis ini menitikberatkan beban torsional yang terjadi hanya pada bagian kritis sehingga mengakibatkan adanya tegangan ekuivalen, karena pada bagian lain tegangan ekuivalent yang terjadi relatif kecil. Gambar 3. adalah fillet crankshaft, di mana merupakan bagian kritis dari crankshaft. Tegangan maksimum pada fillet merupakan efek dari gaya sentrifugal dan getaran ${ }^{(9)}$. 


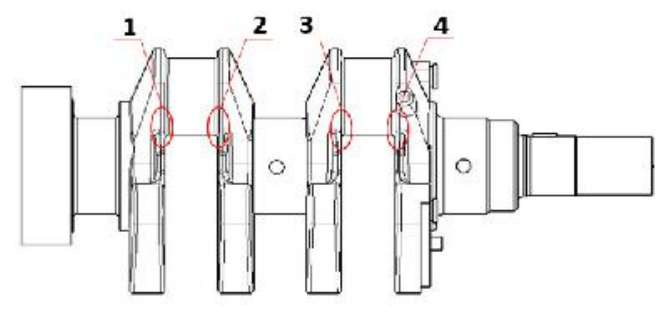

Gambar 3.

Fillet, bagian kritis crankshaft

\section{Kondisi batas untuk analisis transient}

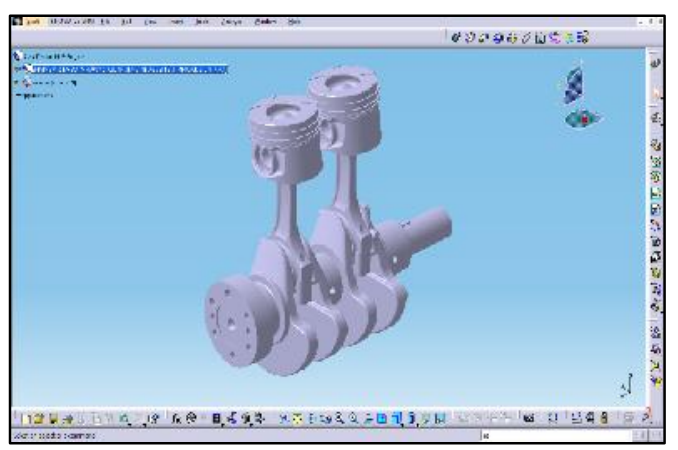

Gambar 4.

Connection pada analisis crankshaft

Untuk sambungan antar komponen dalam analisis transien ini menggunakan joint body-body serta menggunakan joint body-ground. Dari sambungan antar komponen tersebut ada bermacam-macam tipe seperti fixed, revolute dan cylindrical. Pemakaian sambungan disesuaikan dengan kemungkinan gerak yang akan dialami oleh komponen.

\section{Meshing}
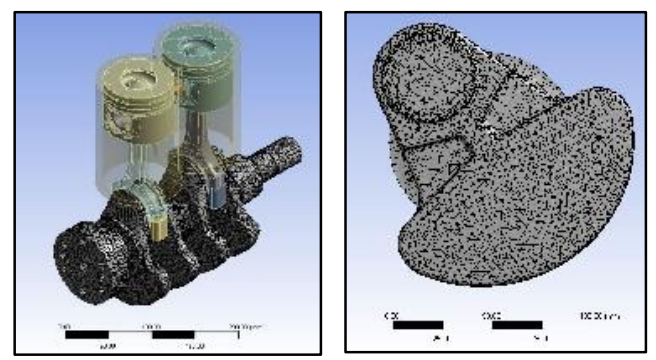

Gambar 5.

Meshing Crankshaft

Meshing adalah kesatuan proses dalam simulasi metode elemen hingga. Meshing memberikan pengaruh yang signifikan pada keakurasian, konvergensi dan kecepatan suatu solusi metode elemen hingga. Pada kasus ini, meshing hanya dikenakan pada komponen crankshaft seperti pada gambar 5 , di mana jenis meshingnya adalah tetrahedron.

\section{Pembebanan}

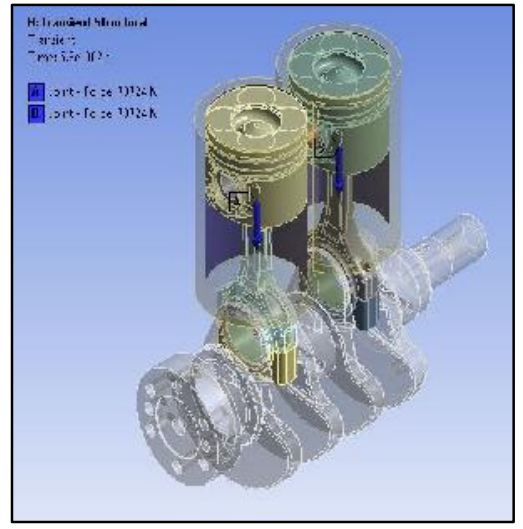

Gambar 6.

Gaya yang bekerja pada piston

Sesuai dengan kaidah pembakaran internal dua silinder empat stroke maka kerja kedua piston tersebut tidak bersamaan. Penggunaan analisis transient membantu perbedaan input gaya berdasarkan waktu.

Untuk memodelkan pembakaran yang terjadi, maka analisis transien dilakukan pada dua siklus. Siklus pertama untuk memodelkan pembakaran pada silinder dengan piston $\mathrm{A}$, sedangkan siklus kedua untuk memodelkan pembakaran pada silinder dengan piston $\mathrm{B}$ ditambah dengan gaya inersia yang masih tersimpan akibat proses pembakaran sebelumnya.

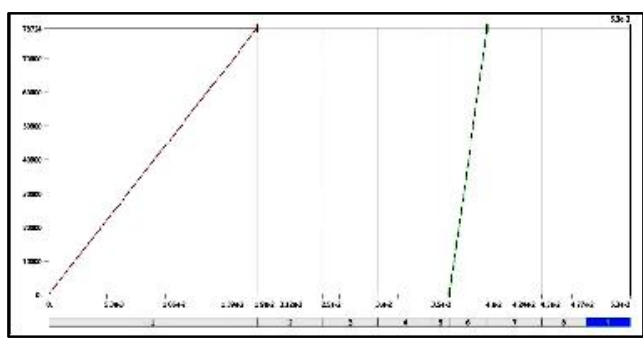

Gambar 7.

Load Step pada Piston A dan Piston B

Dengan mempertimbangkan kebutuhan permodelan tersebut di atas dilakukan dengan menggunakan timestep yang relevan. Pada gambar 8 . Ditunjukan time step dengan masing-masing load stepnya.

0 1.9e-002 Seconds: - Gaya sebesar $78724 \mathrm{~N}$ dikenakan hanya pada piston A. sedangkan di Piston $\mathrm{B}$ gaya masih $0 \mathrm{~N}$. 
2.5e-002 5.3e-002 Seconds: - Gaya di Piston A mengalami deaktif.

4e-002 Seconds: - Gaya sebesar 78724 N dikenakan hanya pada piston $B$, di mana kondisi Piston $\mathrm{A}$ deaktif.

4.5e-002 5.3e-002 Seconds: - Gaya di Piston B mengalami deaktif.

Tabel 4.

Time step terhadap load step

\begin{tabular}{|c|c|c|c|}
\hline No & Waktu & $\begin{array}{c}\text { Gaya } \\
\text { Piston } \\
\text { A }\end{array}$ & $\begin{array}{c}\text { Gaya } \\
\text { Piston } \\
\text { B }\end{array}$ \\
\hline \multirow{2}{*}{1} & 0 & 0 & \multirow{6}{*}{0} \\
\hline & $1.90 \mathrm{E}-02$ & 78724 & \\
\hline 2 & $2.50 \mathrm{E}-02$ & \multirow{8}{*}{78724} & \\
\hline 3 & 3.00E-02 & & \\
\hline 4 & $3.50 \mathrm{E}-02$ & & \\
\hline 5 & 3.65E-02 & & \\
\hline 6 & 4.00E-02 & & \multirow[t]{2}{*}{78724} \\
\hline 7 & 4.50E-02 & & \\
\hline 8 & 4.90E-02 & & 78724 \\
\hline 9 & 5.30E-02 & & \\
\hline
\end{tabular}

Penentuan hasil analisis transien berupa tegangan ekuivalen dilakukan dengan proses iterasi berdasarkan time step yang sesuai meskipun beberapa teori menjelaskan lebih detail tentang metode pemilihan time step dengan menggunakan perhitungan analistis.

Pada gambar 8. Terlihat siklus deformasi yang terjadi pada proses time step yang menunjukan bahwa time step yang dipilih sudah sesuai dan konvergen.

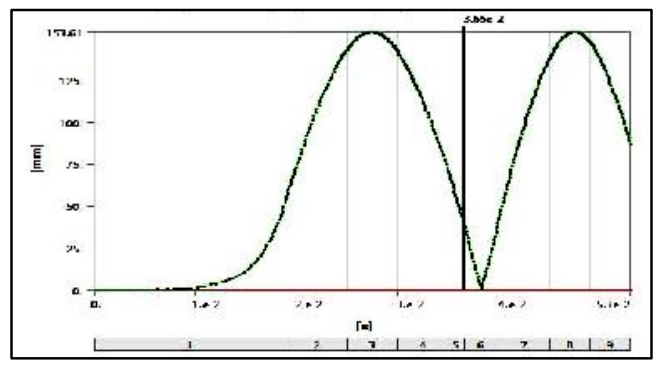

Gambar 8.

Grafik deformasi vs waktu operasi crankshaft

\section{Perhitungan RPM}

Hal yang diharapkan dari pembebanan sebesar 78724 adalah kecepatan putar crankshaft sebesar $3600 \mathrm{rpm}$. Dari hasil analisa sementara pada gambar 8 . Menunjukan bahwa crankshaft bekerja pada kecepatan putar sebagai berikut:

$$
\text { Siklus I (piston A) } \begin{aligned}
\mathrm{t} & =0.037 / \text { rotasi } \\
& =26 \mathrm{rps} \\
& =1600 \mathrm{rpm}
\end{aligned}
$$

Siklus II (piston B) $t=0.02 /$ rotasi

$$
\begin{aligned}
& =50 \mathrm{rps} \\
& =3000 \mathrm{rpm}
\end{aligned}
$$

Siklus yang diinginkan sebesar $3600 \mathrm{rpm}$ dapat terjadi setelah dua atau tiga siklus. Hal ini menunjukan kesesuaian antara input gaya dan kecepatan putar yang terjadi.

\section{Hasil dan pembahasan}

Tegangan ekuivalen terjadi pada masingmasing crankpin, pada bagian filletnya. Tegangan ekuivalen maksimum terjadi sesaat setiap satu siklus secara bergantian antara piston A dan Piston B seperti yang ditunjukan pada gambar 9., detil penjelasan ada pada poin 5.6.1 dan 5.6.2

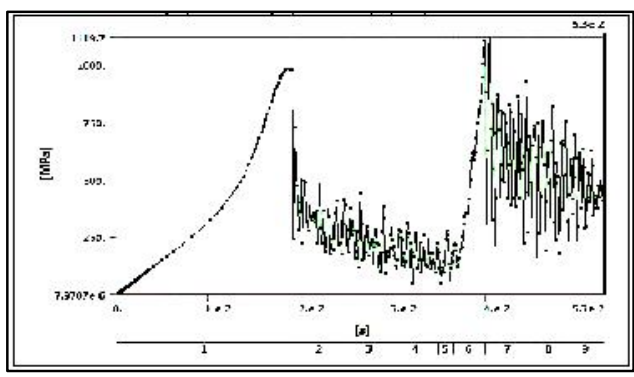

Gambar 9.

Grafik tegangan ekuivalen vs waktu operasi crankshaft

\section{Tegangan ekuivalen pada load step I (piston A)}

Saat piston A bekerja dengan gaya 78724 $\mathrm{N}$ pada detik ke $1.9 \mathrm{e}-002$, bagian fillet crankshaft mengalami tegangan ekuivalen (von-misses) sebesar 982.1 Mpa yang kemudian tegangan pada crankshaft mengalami penurunan secara periodik, letak tegangan ekuivalen maksimum dapat dilihat pada gambar 10 dan gambar 11. 


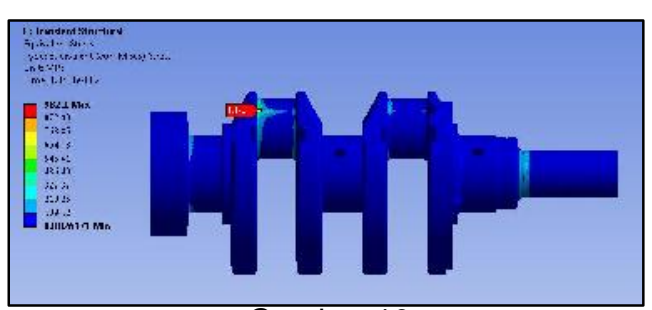

Gambar 10

Tegangan ekuivalen maksimum piston $\mathrm{A}$ di daerah fillet.

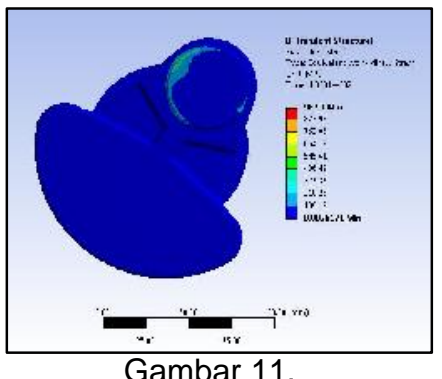

Tegangan ekuivalen yang terjadi pada potongan penampang fillet

\section{Tegangan ekuivalen pada load step II (piston B)}

Saat piston B mendapatkan gaya yang sama dengan piston A maka tegangan di sekitar fillet mengalami peningkatan seperti mengalami beban impact, tegangan ekuvalen yang terjadi adalah sebesar 1119.7 Mpa, letak tegangan ekuivalent maksimum dapat dilihat pada gambar 12 dan gambar 13.

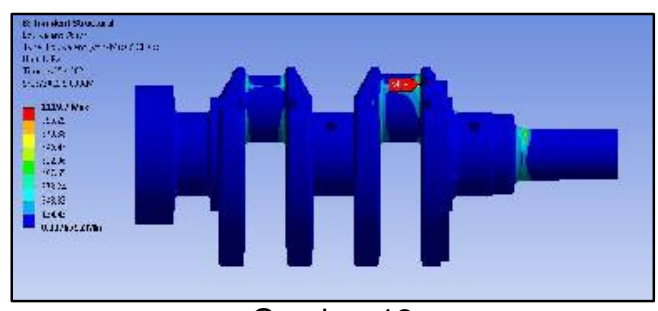

Gambar 12

Tegangan ekuivalen maksimum piston $B$ di daerah fillet.

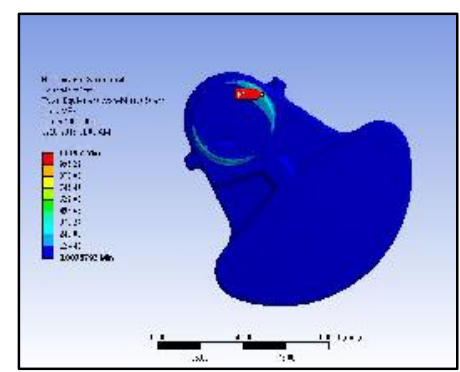

Gambar 13

Tegangan ekuivalen yang terjadi pada penampang fillet piston $\mathrm{B}$.

\section{Kedalaman konsentrasi tegangan ekuivalen}

Konsentrasi tegangan ekuivalen yang terjadi pada fillet crankshaft hanya terjadi di sekitar permukaan, dengan kedalaman antara 0 sampai $2.5 \mathrm{~mm}$, dapat dilihat pada gambar 14 dan gambar 15. Hal tersebut yang menjadi pokok bahasan dari makalah ini, bahwa untuk crankshaft yang mengalami beban siklik sehingga tegangan di sekitar permukaan menjadi besar maka diperlukan sebuah perlakuan permukaan. Perlakuan permukaan yang dimaksud adalah pengerasan permukaan untuk meningkatkan kekerasan permukaan.

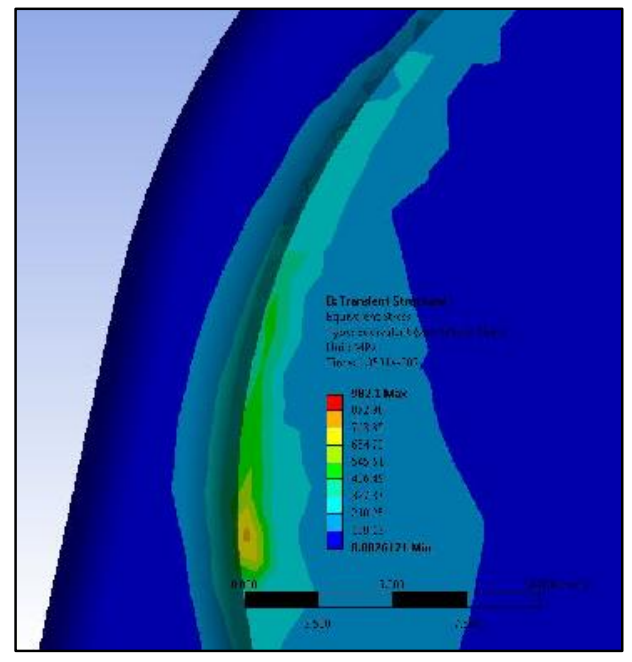

Gambar 14.

Kedalaman konsentrasi tegangan ekuivalen maksimum fillet pada piston $A$.

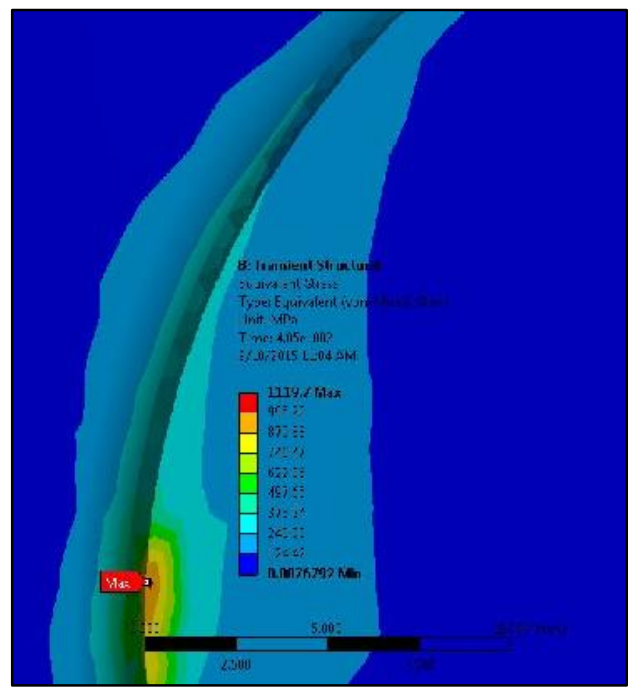

Gambar 15.

Kedalaman konsentrasi tegangan ekuivalen maksimum fillet pada piston $B$. 


\section{SIMPULAN DAN SARAN}

Pada makalah ini masukan gaya yang digunakan sebagai pembebanan adalah sebesar $78723.91 \mathrm{~N}$, di mana gaya tersebut bekerja secara bergantian pada tiap silinder. Tegangan ekuivalen maksimum yang dihasilkan adalah 1119.7 Mpa, terletak pada fillet. Dari besar gaya dan hasil tegangan ekuivalen merupakan kondisi ekstrim ketika mesin mengalami knocking atau saat menerima beban impact.

Kedalaman tegangan ekuivalen adalah \pm $2.5 \mathrm{~mm}$, di mana dapat dijadikan acuan untuk proses perlakukan permukaan berupa pengerasan permukaan sehingga diharapkan konsentrasi tegangan ekuivalen maksimum dapat berkurang, atau dapat meningkatkan nilai kekuatan luluh dari material baja tersebut.

Dari segi desain geometri, penerapan radius dari fillet dapat mengurangi konsentrasi tegangan.

Analisis transient dinamis lebih memberikan hasil yang faktual dibandingkan dengan statis, hal tersebut sesuai dengan kaidah kerja pembakaran internal sebuah mesin. Di mana dalam satu waktu antara piston satu dengan yang lain tidak berada dalam langkah kerja yang sama.

Studi ini masih dapat dikembangkan pada tahap selanjutnya, di mana metode pengerasan permukaan yang beragam dapat dipilih sesuai dengan keuntungan dan kerugian baik dari segi waktu maupun dari segi proses.

\section{DAFTAR PUSTAKA}

1. Rajesh, Mane; Manoj, Ukhande. "Crankshaft Fatigue Test Validation using CAE", Asia Forge, International Forging Conference, Delhi, pp. 1-2. (2008)

2. Shrikant B. Gawas Mr. Pranit M. Patil, "Prototype of Mechanisms using Fused Deposition Modelling Process," International Journal Of Engineering Science and Research Technology, pp. 438-442, 2014.
3. Montazersadgh and Ali Fatemi, "Optimization of a Forged Steel Crankshaft Subject to Dynamic Loading", SAE International, Paper 2008-01-0432

4. K. D Alex, Arjun. P, Hassan K, Vysak P.,"FEA Approach to Dynamic Analysis of Crankshaft"., Proceedings of the "National Conference on Emerging Trends In Mechanical Engineering 2k13" NCETIME - 2k13.

5. Singh, Anku Kumar., "Establishing Core Hardness by Induction Hardening Process for Crankshaft"., IJESRT., ISSN: 2277-9655.

6. R.J Deshbhratar, Y.R Suple, " Analysis and optimization of Crankshaft using FEM", International Journal of Modern Engineering Reasearch, vol-2, issue-5, ISSN:2249-6645, pages:3086-3088, Sept-Oct 2012.

7. Varun. B., "Stress Analysis and Optimization of Crankshafts Subject to Static Loading" International Journal Of Engineering And Computer Science ISSN:2319-7242; Volume 3 Issue 5 May, 2014 Page No. 5579-5587

8. Mayer. H. M, C. Achmus, A. Pyzalla, W. Reimers.,2000,. "Increase of fatigue strength of Crankshafts by Deep-Rolling and Induction Hardening Induced Beneficial Residual Stress States"., Materials Science Forum.

9. Fonte. M., V. Anes., P. Duarte., L. Reis., M. Freitas., "Crankshaft failure analysis of a boxer diesel motor" Engineering Failure Analysis 56 (2015) 109-115.

10. Palin-Luc. T., D. Couparda., C. Dumasb., P. Bristielc., "Simulation of multiaxial fatigue strength of steel component treated by surface induction hardening and comparison with experimental results" International Journal of Fatigue, Volume 33, Issue 8, August 2011, Pages 1040-1047. 